Richard C. Hoffmann

\title{
A brief history of aquatic resource use in medieval Europe
}

Received: 30 April 2004/ Revised: 31 August 2004/ Accepted: 9 September 2004/Published online: 11 December 2004

(C) Springer-Verlag and AWI 2004

\begin{abstract}
Humans have exploited European aquatic resources since at least the Palaeolithic, but during the Middle Ages rising human populations and demand initiated great changes in many fisheries. To help understand the past and present of the Wadden Sea, this paper sets the main developments of medieval fisheries in the context of changing larger European social and aquatic environments ca. 500-1500 A.D. Anthropogenic influences on fish populations and aquatic habitats interacted with natural environmental variations. Both nutritional and cultural needs shaped human consumption of aquatic organisms. Many fisheries met the demand for food by economic reorientation from subsistence to artisanal and then even fully commercial purposes. Exploitation slowly shifted from limited or deteriorating local inland and inshore fish populations to frontier, commonly marine, and increasingly pelagic resources. Some inland regions developed aquaculture to enhance local supplies of fresh fish. General processes are illustrated by case studies of selected indicator species from freshwater and marine habitats generally pertinent to the region surrounding the Wadden Sea. Anadromous salmon (Salmo salar) and sturgeon (Acipenser sturio) were negatively affected by overfishing and by unintentional human alteration of critical habitat. Habitat preferences of catadromous eel (Anguilla anguilla) and exotic carp (Cyprinus carpio) let these species gain from medieval human activities. In the case of herring (Clupea harengus), Europe's largest early commercial marine fishery, technological innovations which raised production and consumption played off against long-term consequences of intensely exploiting sensitive natural systems.
\end{abstract}

Communicated by H.K. Lotze and K. Reise

R. C. Hoffmann

Department of History, York University,

4700 Keele Street, Toronto, Ontario,

M3J 1P3, Canada

E-mail: medfish@yorku.ca

Tel.: + 1-4167365123

Fax: + 1-416 7365836
Keywords Aquaculture - Fisheries - Human impact · Environmental change $\cdot$ History

\section{Introduction}

Humans have surely pursued, captured, and consumed aquatic organisms since at least the Palaeolithic, but the task of this report is to bring fisheries into the context of long-term changes in Latin Christian Europe between about 500 and 1500 A.D., the period conventionally called the 'Middle Ages'. This will place estuarine and tidal ecosystems such as the Wadden Sea in a slow historic shift from human exploitation of local inland and inshore habitats to exploitation of frontier, commonly marine, increasingly pelagic resources. It will further recognize the contingent interaction, long before the modern age, between natural environmental variations and human-induced changes (resource exploitation to the point of overfishing, habitat alteration, eutrophication) with detectable ecological consequences.

Natural environmental changes during the medieval millennium occurred at several scales. These notably involved: (1) Holocene-scale shifts in water levels, inland and marine, and post-glacial recolonization of northwestern Europe by various fishes; (2) century-scale climatic change averaging about $1{ }^{\circ} \mathrm{C}$ from a "Medieval Warm Period" during the tenth to twelfth centuries to the "Little Ice Age" of the fourteenth to nineteenth centuries; and (3) distinctive regional manifestations within both climatic periods which included, at least during the Little Ice Age, decade-scale variabilities of more than average magnitude in both temperature and precipitation (Grove 1996; Brázdil 2002, 2003).

Europe at the end of the Roman hegemony was certainly no pristine landscape. Quite apart from other activities, humans had evidently been exploiting freshwater and near-shore marine organisms throughout the Neolithic, Bronze and Iron Ages. It is unlikely, however, apart from a few Mediterranean locales, that this pre- 
medieval exploitation detectably affected the structure or function of aquatic ecosystems (Hoffmann 1996).

Three themes then characterized aquatic resource use in Europe during the medieval millennium. Nutritional and cultural needs shaped medieval demand for, and consumption of, aquatic organisms. Fisheries evolved within larger socio-economic contexts, not just the rise and decline of human numbers, but also the formation and spread of more complex economic and political institutions. General economic development and economic development specific to fishing activities affected aquatic ecosystems first in inland and coastal Europe, and later also on marine resource frontiers.

\section{Nutritional and cultural needs}

Nutritional and cultural needs shaped medieval demand and consumption of fishes and other aquatic organisms (for what follows see Scully 1995; Hoffmann 2000; and both the modern scholarship and medieval texts cited therein). Medieval Europeans obtained most of their calories from cereals and liked fish less than meat with their bread or porridge, but they did eat fish too. Reasons for this demand conditioned their exploitation of aquatic resources. It is probably important here to note that medieval peoples classified all water-living creatures as 'fish', contrasted with terrestrial 'animals', aerial 'birds', creeping 'snakes' and 'worms'.

People certainly sought fish for what we, not they, would call 'protein', namely as dietary substitute for meat food, providing expensive calories but desirable nutrients. But their demand for that food was structured on cultural grounds, involving penance, health, and prestige. By the fifth or sixth century, newly dominant Christianity had a scale of taboos on eating terrestrial 'flesh', but western Christians in particular allowed most people to substitute fish on the roughly 130 days $(35 \%)$ of the year when ideology forbade them 'meat'. This encouraged those who could afford fish to eat it weekly and seasonally, so modulating demand. Medical concepts of a healthy diet justified eating flesh and, less eagerly, fish, while strongly promoting fresh over salted fish. Varietal preferences, though articulated by many writers, were less systematic. And finally, high social rank was recognisably displayed by a table with large, fresh, expensive fishes. Prelates, for instance, proverbially enjoyed their pike (Esox lucius), salmon (Salmo salar) and sturgeon (Acipenser sturio). Popular voices generally acknowledged fish to be an expensive food for the rich, ein herren speis (Wiessner 1931; Wiessner 1936).

Garbage heaps, menu lists, kitchen accounts, and other archaeological and historical evidence is unanimous: medieval people did consume these organisms. Early on, especially before about 1100 , they relied on species available in their own locality, which meant mostly freshwater or diadromous fishes, which were consumed fresh or lightly preserved. Eventually, and especially from the twelfth century, they came to eat an increasing share of marine species in durably preserved (salted, dried, brined) form and thus supplied from greater distances. Elites, however, resisted these preserved fishes, staying as much as possible with fresh local supplies including, in interior Europe, the cultured exotic common carp (Cyprinus carpio), native only to southeastern Europe (Hoffmann 1994). Where full rations can be reconstructed, fish provided up to $3-5 \%$ of calories but cost 10-20\% of food budgets (Hoffmann 2000 and sources cited therein).

\section{Organisation of fisheries}

Europe's fisheries evolved to meet human needs within a larger pattern of medieval socio-economic development. In the earlier Middle Ages (into the twelfth to thirteenth centuries) subsistence fisheries predominated (and some remained locally important well into modern times). In a subsistence fishery, the catch fed the household of the fisher, whether he was its patriarchal head (direct subsistence) or a servant supplying a larger establishment (indirect subsistence). Records of fishing activities, and both verbal and material evidence of taxa consumed, indicate that fishing for the consuming household exploited local waters and fish populations everywhere. Direct subsistence was a part-time seasonal activity of peasant households and communities who had access (not always formally legal) to local aquatic resources and who historically resisted exclusive private rights to those resources. These people had deep empirical familiarity with local organisms and ecosystems. Indirect subsistence fed local elite households from the lord's resources (increasingly conceived as 'his', be it by proprietary right or royal grant) with the labour of subordinates, whether servile peasants or household servants working part-time or specialist 'fishers' employed fulltime. The most elaborate seigneurial organisations were found where large consumers (princes, ecclesiastical foundations) lived beside water bodies (lakes, rivers) large enough to support a year-round fishery. Subsistence fishers of both types had the same tool kit with a variety of basic capture techniques, from small-scale pot gear or baited hooks to large weirs and crew-served nets. Passive technologies with large fixed installations yielded big seasonal catches which could be stored alive in tanks, cages, or ponds, or preserved with simple, short-run methods (drying, smoking, salting) (Hoffmann 2000).

In about the tenth century, records from several European regions show people catching fish for sale to nearby consumers, so practicing the kind of small-scale commercial fishery we now call artisanal (Hoffmann 2000). Local markets for fish were an integral, indeed often precocious, element in the early rise of an exchange sector, i.e. the start of what historians call the 'Commercial Revolution of the Middle Ages' which became fully visible as it grew during the eleventh and twelfth centuries. Artisan fishers first appeared at inland and coastal sites with access to consuming centres, especially 
emerging towns such as Ravenna, Gdansk, Dieppe, Lincoln or Worms, and such people 'who make their living from fishing' spread and multiplied from there. Well documented later cases confirm that especially specialist providers of indirect subsistence to lords found other people prepared to pay for fish the lord thought surplus; those potential consumers with cash in their purses were mainly townsfolk-merchants, officials, artisans - not peasant cultivators. Full emancipation of artisan fishers from their lord's claims - or conversion of those claims into a licencing or access fee - came very slowly. Artisan fishing was commonly one of several different household enterprises in local societies, rather than the predominant activity for a whole settlement. These fishers' localized economic focus and small-scale methods for harvesting local resources are confirmed whenever urban, village or regional communities evolved collective (guild) institutions, whose stereotypical self-regulation also include common management of resources and market opportunities.

Local markets distributed fresh catches from nearby waters - whether offered by fishers, their wives, or specialized fishmongers - and only slowly also animals taken farther away. That greater distance could be temporal, as when seasonally abundant catches, e.g. herring (Clupea harengus) in the north, sardine (Sardina pilchardus) in the south, were preserved for later, especially Lenten, consumption. Even well into the thirteenth century these taxa were taken from fishers' home waters and eaten in quantity only a few score kilometres inland. Other fishes came eventually across wider spaces: by the mid-thirteenth century fast horse relays sped fresh marine fishes from Normandy to Paris (but no further) (Auzary-Schmaltz 1995; Bourlet 1995); by the early 14th, cart traffic with coastal fishes covered interior England. Fishmongers typically organized such transport to pool regional catches and balance seasonal abundances of different varieties. Many maintained live storage facilities and some helped capitalize fishers by advance purchase of their catches.

Medieval subsistence and artisan fishers alike selected from the same diverse technologies those appropriate for taking and preserving familiar local taxa. Rare written traces of this small-scale enterprise allow no quantifying of catches or, given the diversity, comparing prices of different varieties. The evidence does indicate markets growing continually since the twelfth century, and a sense among contemporaries that prices were rising. Twelfth-century Paris philosophy professor Peter Abelard acknowledged fish to be expensive food (Zimmermann 1973).

\section{Human environmental impacts}

Medieval fishing activities and the unintended consequences of large-scale European agricultural, urban and commercial development during the Middle Ages combined to affect aquatic ecosystems and their constituent fish species. Water quality, habitat and biodiversity were impacted (for extended discussions of most topics in this section see Hoffmann 1996, 2000, 2002). When people cleared woodlands for permanent arable fields across large areas of Europe, they destabilized many hydraulic regimes. In about 1300, an Alsatian chronicler commented on changes in seasonal stream-flow within his lifetime. Barrier dams built to drive water mills on higher-order streams fragmented riverine habitats. Contemporaries observed negative effects on migratory fishes in, for instance, the River Sarca in 1210 and the Dhünn in about 1470. Accelerated erosion-siltation episodes associated with phases of regional arable expansion and, subsequently, with changes in agricultural land-use practices are visible from England and France east to Poland. These altered deposition patterns (and arguably also water chemistry) in rivers, estuaries and coasts: by the twelfth century the Oude Rhin channel had silted shut below Leiden; the onetime bay at the mouth of the Vistula became a delta in the thirteenth century. Even eutrophication from dense, mainly urban, populations can be detected archaeologically on the Bodensee shore at later-medieval Konstanz, while a royal ordinance of 1415 tried to mitigate the infectee et corrumpue' Seine below Paris. Observers blamed fish kills on toxic effluents from, for instance, processing hemp and flax fibres or metallic ores in the low countries, Tuscany and central Europe (Agricola 1556; Stolz 1936; Trexler 1974; Materne 1988; Plouchard 1997). Meanwhile, observed changes in abundance, size and ranges of fish taxa traditionally favoured as food strongly suggest their overexploitation. Consequent shifts in relative abundance and species composition of certain regional fish populations are evidenced by archaeozoology and by verbal records of human behaviour with respect to their fisheries.

Contemporary human perceptions, understandings and behavioural responses suggest the effects of changing aquatic systems. Though fish never provided cheap calories, rising prices indicated demand in excess of traditional supply and motivated more fishing effort. A thousand salt herring at Calais, for example, which went for 15 sols in 1268, cost 30 sols in 1300 and 75 sols in 1342 (Hocquet 1987). Accelerated privatisation of valued fisheries resources, both inland and coastal, constrained subsistence use by local communities and imposed some economic rent on artisanal users. Enlarged public regulation of fisheries (e.g. Sicilian laws of 1231, French ordinances from 1268), was often articulated in terms of conservation and sustainability. Edward I of England imposed rules around the Channel Islands 'for the sake of the conger' (Conger conger). Authorities set minimum size limits, seasonal closures, and restrictions on gear; they assigned enforcement to specialised officials or those generally responsible for local and regional public order. The new laws compel the inference that at least some groups with political clout perceived changes in the status of certain fish taxa, most often freshwater, estuarine or anadromous. 
Medieval Europeans further intervened at several levels with the intent of manipulating their aquatic systems. Local stocking and species transfer was always an option, one advised in estate management manuals and to be seen in practice from Sicilian lagoons to Yorkshire rivers. In about 1400 , one French landowner even recorded his experiments with artificial spawning of salmonid fishes. Purposeful habitat modification has been extended since the eleventh century to include the construction of on-stream ponds, while an early fourteenthcentury German didactic poem advised the use of straw as an artificial spawning substrate. Aquaculture was a major area of innovation in medieval Europe, with the development, perhaps first in eleventh- to twelfth-century France, of distinctive (not borrowed) techniques for rearing, in particular, cyprinids, pike, and other lentic species. By and after 1300, whole inland regions were producing carp on a large scale by this means (Hoffmann 2000, 2002).

\section{Ecological consequences for some indicator species}

Ecological consequences of the developing medieval economy in general, and that of fisheries in particular, are best tracked by observing well-documented indicator and/or keystone species from different habitat zones with relevance to the Wadden Sea. Several potential outcomes can be recognized from certain freshwater and estuarine taxa: first two, salmon and sturgeon, which sustained negative effects; then two others, eel and carp, which plausibly gained from human activity.

Abundant migratory adults of the anadromous Atlantic salmon supported active local fisheries and prestigious conspicuous consumption in the early Middle Ages throughout the species' European rangesouth to the Douro and deep into the interior of Atlantic watersheds. A subsequent long decline of salmon populations was well recognized by local authorities, who rightly blamed overfishing and artificial barriers to spawning migrations (Halard 1983; Hoffmann 1996). That the principal impact was on those gene pools most adapted to the highest tributaries is confirmed by a late medieval shift of salmon fisheries in developed western regions down to large estuaries, and by the expansion of commercial production in European frontier areas where thinner agricultural development and local demand had not so diminished the runs (Fig. 1). By the fifteenth century, salted and barrelled salmon from east Prussia supplied central German consumers who had earlier trapped their own; Parisians were then eating Scottish and Irish salmon imported via Norman ports, where centuries of older records had traced the decline of local runs (Benecke 1880; Willam 1961; Martens 1997; Halard 1983; Gemmill and Mayhew 1995). This northward retreat of salmon in later medieval Europe coincided with the climatic cooling (early Little Ice Age) which Carlson (1996) has proposed as necessary for that species' simultaneous southward extension of range in eastern North America. If the same favourable conditions saw European salmon stocks contract in certain regions, this must surely be attributed to the well-documented pattern of overfishing and habitat loss there.

Human activity had thus by the end of the Middle Ages affected local and regional spawning populations of migratory salmon in several of the more developed areas of western Europe. In response, people to some degree diverted fishing pressure to more peripheral areas.

The common or European sturgeon (A. sturio) consumes benthic invertebrates and small fishes. Long-lived adults grow slowly to $3.5 \mathrm{~m}$ and $300-400 \mathrm{~kg}$ (http:// www.fishbase.org) and now enter freshwater only to spawn over gravelly bottoms of large rivers. The young live for some years in rivers and estuaries (Bemis and Kynard 1997). This now rare animal, protected throughout its European coastal range, was for early medieval elites a frequent and prized culinary treat. In layers dated to the seventh to ninth century at 17 southern Baltic archaeological sites, for instance, this species provided up to $70 \%$ of fish consumed (Benecke 1986).

Already by the twelfth century, fishing pressure and human modification of riverine and estuarine habitats threatened sturgeon populations from Italy to the Baltic. Archaeological and verbal sources everywhere track declines in the frequency, relative share and mean size of these fish, to the point where they

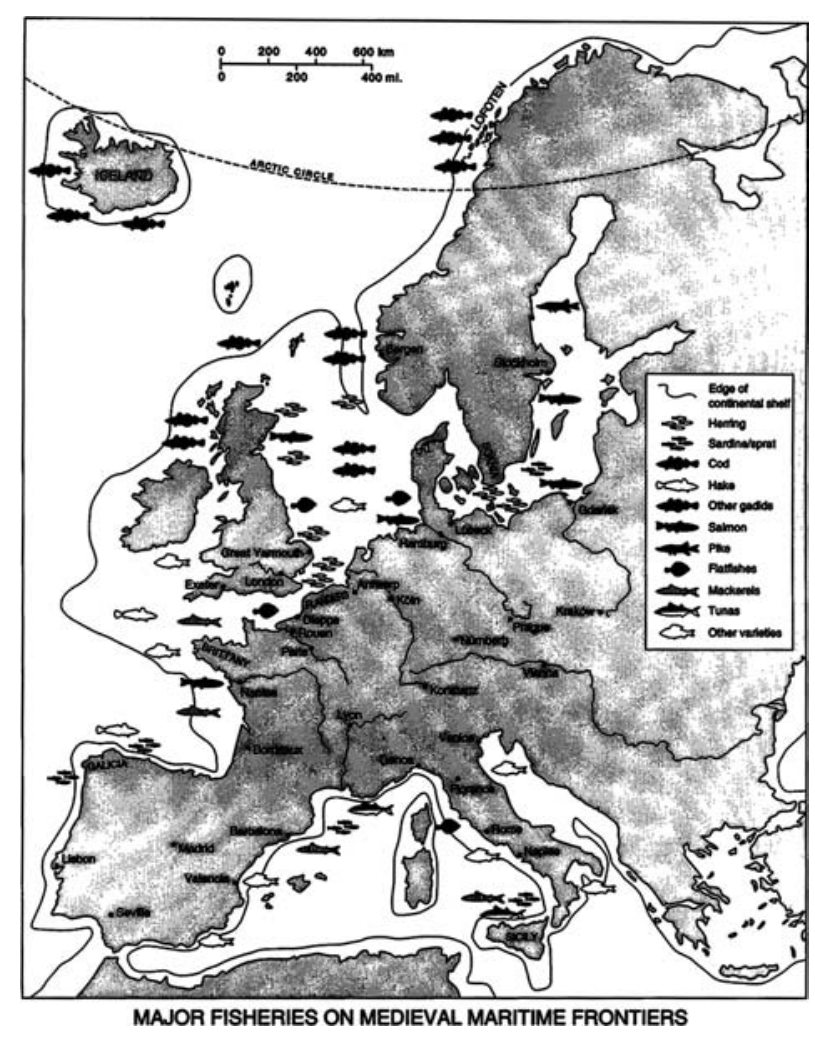

Fig. 1 Major fisheries on medieval maritime frontiers 
vanished from all but the highest social settings (becoming a 'royal fish') and elite chefs passed around recipes to 'make sturgeon' from veal (Alan of Lille 1978; Clason et al. 1979; Van Neer and Ervynck 1993; Clavel 2001). Two intriguing incidents are useful reminders that forces other than human also drove historic processes of change. New genetic studies (Ludwig et al. 2002) suggest a transatlantic movement of the North American species A. oxyrinchus during the ninth to thirteenth centuries, when North Atlantic temperatures were distinctly warmer than in the later period, and subsequent interbreeding or replacement of the northernmost populations of A. sturio. Older research also found sturgeon catches around the Rhine-Maas estuary reviving for a time after 1400, when great storm floods had destroyed some centuries' accumulation of barrier dams and dikes (Boddeke 1971). Despite these important continuing natural influences on the range and genetic diversity of $A$. sturio, however, there is little doubt that during the Middle Ages it was human agency that reduced its status from a common to a quantitatively insignificant component of Europe's estuarine ecosystems.

Species with other habitat requirements and ecological niches gained from medieval human activities, expanding population size and range. By at latest the fourteenth century, the common eel had entirely replaced sturgeon as the principal fishery of the Rhône delta (Amargier 1971). Predaceous subadults of this catadromous species were, and are, ubiquitous in temperate Europe's Atlantic and Mediterranean watersheds, ranging from estuaries to lakes and small streams far inland. Their tiny bones and high oil content make eel evasive archaeologically, but regular fishing of eel at weirs, mills and in stillwater habitats along watercourses everywhere supported heavy local consumption of fresh and lightly processed catches throughout the earlier Middle Ages.

Subsequent human activities which greatly enlarged stillwater habitats had the unplanned result of much favouring the eel. Across the whole Rhine delta, for instance, a great and long-term expansion of shallow estuarine and freshwater lakes since at latest the thirteenth century resulted from subsidence of drained peat lands, peat mining, diversion of rivers, rising water levels, and both local and large-scale wave action. These turbid, fertile and accessible lentic habitats soon supported large and lucrative commercial fisheries for eel (van Dam 1998). Comparable explosions in eel fishing took place at about the same time along the Sicilian and Italian shores of the Tyrrhenian Sea, at the mouths of the Po, and in natural lakes of interior Italy, all locations where other kinds of evidence indicate increased lagoon formation, siltation and eutrophication (see, for instance, Bresc 1986, 1987; Vendittelli 1990, 1992; Lanconelli 1985; Biganti 1995; Grove and Rackham 2001; Vincenti 2002). We can so far only speculate on the point of balance for eel between expanded habitat and more intense fishing pressure.
Common carp most distinctly benefitted from both unintentional and quite purposeful medieval human actions (what follows here is extensively treated from several perspectives in Hoffmann 1994, 1996, 2000, 2002). Up to the seventh century, all securely datable evidence of this omnivorous inhabitant of warm, turbid, still water is limited to the Black Sea drainages of the Balkan peninsula, including the Danube system below Pannonia (Fig. 2). Thereafter, live transport and storage of wild-caught fish at elite consumption sites (castles, monasteries) helped spread the tough and tolerant exotic to the Rhine watershed by the twelfth century and into the Atlantic watersheds of France in the thirteenth century. In 1258, employees of Count Thibaut V of Champagne, for instance, were stocking hundreds of carp fry in ponds at Igny-le-Jard on the Marne. Other people later took carp across salt water to England and Scandinavia.

Entrepreneurs like Count Thibaut purposely developed large-scale artificial aquaculture in the post-1200 medieval west. Using innovative new techniques, they managed enhanced natural or fully artificial water bodies to rear this fast-growing exotic from eggs and larvae to consumption size, whether for (indirect) subsistence or for market sale. This is not the place to detail the technology and economics, nor the complex social and ecological consequences, some plainly quite unintended, of medieval carp culture. Suffice to note that parallels with today's aquaculture of Atlantic salmon are impressive.

\section{Resource frontiers}

To aquacultural manipulation in response to demand for fish outstripping traditional local wild supply, medieval Europeans added a major intensification and expansion of effort to exploit fisheries on resource frontiers. This drove commercialisation to a capitalist scale in what had

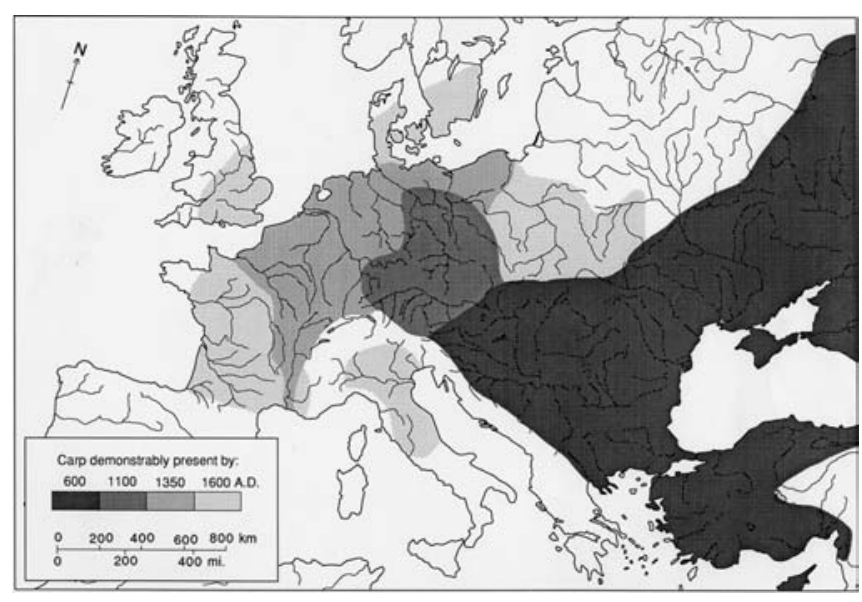

Fig. 2 The spread of carp from southeastern to northwestern Europe during the Middle Ages 
hitherto been local subsistence or artisanal fisheries on coastal (and eastern) margins of the European economy, followed by continual expansion to ever more distant waters, especially as what had once been frontiers were themselves affected by overfishing and habitat changes of human origin. Innovative means to catch, preserve or market these fishes kept enlarging supply to far-off consumption markets (Hoffmann 2002).

As a case in point, consider the pelagic, planktoneating herring, with medieval fisheries evolving under conditions of both human and environmental change. Since the 1200s, certain regionally defined breeding populations of herring were set at risk when locally intensified human exploitation for staple export coincided with changes to water chemistry and sediment loads resulting from human agricultural development or left the fish vulnerable to more general and independently documented climatic instability (Hoffmann 2001 discusses the medieval herring fishery more fully, but with less ecological and climatological context than here).

Migratory shoals of herring form reproductively isolated local spawning populations during summer in the offshore North Sea and Atlantic, in early autumn along Baltic and East Anglian coasts, and by November on Flemish and Picard shores (Hodgson 1957; Bailey and Steele 1992; Krovnin and Rodionov 1992). Vast quantities of $16-32 \mathrm{~cm}$ fish could once be caught within sight of land, but saving them to eat even a day or two later required their oily flesh to be kept from the air, smoked or treated with salt.

Early medieval coast-dwellers from Sussex to Sweden ate herring they caught from local shorelines and estuarine stocks (Enghoff 1999, 2000). By about 1000, they were also supplying the fish to nearby inland consumers and, with the subsequent upturn of human numbers and economic activity, the fishery grew rapidly. The first strong evidence of heavy commercial use comes from the southern shores of the North Sea (Hocquet 1987; Clavel 2001) and the Pomeranian coast of the Baltic (Leciejewicz 1985, 1991) (Fig.1). Most of that catch was piled up whole right on the foreshore and covered with salt, making loose dry sapoudre herring with a few months' storage life, then sold in bundles of a thousand.

In the thirteenth century, large-scale commercial exploitation intensified on near-shore spawning concentrations in the southern North Sea (off Great Yarmouth) and at the entrance to the Baltic along the then Danish Scania and peddled its product up to a few $100 \mathrm{~km}$ inland. By the early 1300s, moreover, some of the hundreds of millions of herring taken each year were being packed in barrels with salt brine, perhaps after a special gutting technique - later called kaken-left an intestinal enzyme with more preservative effect (for examples see Enghoff 1999, 2000; Clavel 2001). Innovative processing and packaging made a more durable product which could bear longer shipment and storage (Jahnke 2000).

Later myth associates mastery of the innovations with fourteenth-century Dutch newcomers to the industry. Together with larger vessels equipped for initial processing at sea, these methods won the Dutch access to larger, hitherto untouched, offshore North Sea stocks and to more consumers deeper inland (Unger 1978, 1980; Bruijn 1996; de Boer 1997). Soon, the Dutch dominated the business, mastering the Flemish market shortly after 1400 , entering the Baltic to replace the Hansards as chief suppliers of herring to interior northern Europe, and by the late fifteenth century providing most of the herring imported by the English. Netherlanders even placed herring on Rome's fish market in 1524. At each successive stage of expansion of the herring industry over several medieval centuries, merchant entrepreneurs supplied eager consumers on ever more distant markets with larger production from stocks further offshore.

Small plankton-eating herring comprise a very large biomass near the consuming base of aquatic food webs. Such organisms react quickly and massively to changes in oceanic temperature and nutrient levels (Bailey and Steele 1992; Krovnin and Rodionov 1992). All the animals which eat them are affected in turn. That includes humans: herring catches can fluctuate wildly from one year to the next. On the other hand, the fish were not only well suited to a particular means of preservation, they were available in great seasonal abundance and easily taken with simple gear for immediate processing. The effect was to target fishing effort and impact on specific stocks, at the very time the stocks were defined by their reproductive behaviour.

There are now grounds to suspect that certain spawning populations of herring were under pressure (as evidenced by historically peak catches) just before their commercial collapse, which may then have been triggered by extreme environmental fluctuations. In the late thirteenth century, the south Baltic (Pomeranian) fishery, perhaps as much as 400 years old, disappeared. This followed a century or so of large-scale clearances, soil erosion and flooding in the Odra and Vistula watersheds which feed this part of the sea (Dunin-Wasowicz 1990; Bork 1988; Brázdil and Kotyza 1995). These events, the result of human agricultural development in eastern German and Polish hinterlands, should have affected water chemistry and nutrient levels in estuarine and near-shore areas. Large shoreline changes-filling of bays, formation and consolidation of offshore barrier islands and peninsulas - certainly ensued (Filuk 1968).

Likewise, the heavily-fished herring stocks in the southern North Sea broke down after 1360 and those off Scania collapsed in the 1410s-1420s (Unger 1978; Munro 1994; Jahnke 2000). At this time, contemporaries were observing ferociously unstable weather which historical climatologists now attribute to Europe's transition from the "Medieval Warm Period" to the "Little Ice Age". A cooling pattern with intense storminess had already set in at Europe's northwestern fringe early in the fourteenth century (Bailey 1991) and from the 1390s extended eastward into central Europe, where mean annual temperatures fell until the 1520s. Reduced 
temperatures during spring, summer and autumn characterised these episodes of late-medieval cooling (Pfister et al. 1996; Glaser 2001; Brázdil 2002; compare with Grove and Rackham 2001). These are the seasons when early stages in the herring lifecycle are especially sensitive to varied sea temperatures and food supply: weak year classes now occur in cold years (Krovnin and Rodionov 1992).

Modern research no longer finds herring which concentrate to spawn off East Anglia. The species was not extirpated from the Baltic, but commercial fishing in the main basin shifted to supply more sprats (Sprattus sprattus, a different small plankton-eating Clupeid, more tolerant of low salinity) and on eastern coasts to take a dwarf inshore subspecies (C. harengus membras, "Stremling" or "Strömling") for mainly local consumption. Note, too, that adult Baltic herring in the twentieth century averaged $20 \%$ smaller than those consumed a millennium before (Jahnke 2000). Certainly something changed.

A common scenario was thus arguably re-enacted several times in the medieval herring fishery which fed the European need for a relatively cheap, long-lasting and transportable fish food. Under pressure from growing commercial export demand, long-fished local reproductive concentrations of these animals successively came under more intense exploitation, then crashed to commercial insignificance. Each collapse coincided with independently established environmental variation, whether of plausibly human cause, such as the changing run-off regime from south Baltic watersheds, or of plausibly 'natural' origin, such as the climatic changes which spread eastward from the North Atlantic. The new Dutch fishery at the end of the Middle Ages concentrated on previously unaffected offshore populations, perhaps also less confined gene pools, and in a marine habitat less vulnerable to weather or local runoff. Like salmon, medieval herring should put us in mind of typical present-day fisheries crises with their marketdriven technical innovations, intensification of capital, and continual move outward from commercially depleted to less accessible 'virgin' stocks.

Indeed, all around later-medieval Europe many once subsistence fisheries or untouched fish populations - northern cod (Gadus morhua), hake (Merluccius merluccius) and sardine in Biscay and Channel approaches, pike in the brackish northeastern Baltic, tuna (Thunnus thynnus) in the western Mediterranean-also became subject to new commercial exploitation for distant consumers (Hoffmann 2001, 2002). At a European scale - but always as local manifestations - the closing Middle Ages established new patterns for exploiting aquatic and marine resources. Notably, urban and elite consumers drove mass markets for standardised products from more heavily capitalised fisheries. As greater time and space separated consumers, fishers and natural aquatic systems, habits of constraint were left behind. Yet the distant-water commercial frontier and the artificial aquacultures continued to coexist with traditional artisanal and subsistence use of Europe's shrinking natural fisheries and aquatic systems for a long time.

Acknowledgements The author thanks Dr. Heike Lotze and other organizers of the workshop for the opportunity to present results from historical research to colleagues in other sciences.

\section{References}

Agricola G (1556) De Re Metallica. Froben, Basel, Switzerland Alan of Lille (Alanus ab Insulis) (1978) De planctu naturae. In: Häring NM (ed) Studi Medievali, 3. series, 19(2):797-879 [tr Sheridan JJ (1980) The Plaint of Nature. PIMS, Toronto]

Amargier P (1971) La pêche en Petite Camargue au XIVe siècle. In: Bulletin Philologique et Historique (jusqu'à 1610) du Comité des Travaux Historiques et Scientifiques, 99eme Congrès des Sociétés savantes, Tours, 1968, vol. 1: Les Problèmes de l'alimentation. Bibliotheque National, Paris, France, pp 331-346

Auzary-Schmaltz B (1995) Les Contentieux en matière d'approvisionnement, d'après les registres du parlement de Paris (XIV ${ }^{\mathrm{e}}$ $\mathrm{XV}^{\mathrm{e}}$ siècles). Franco-British Stud 20:49-67

Bailey M (1991) Per impetum maris, natural disaster and economic decline in eastern England, 1275-1350. In: Campbell BMS (ed) Before the black death: studies in the "Crisis" of the early fourteenth century. Manchester University Press, Manchester, pp 184-208

Bailey RS, Steele JH (1992) North sea herring fluctuations. In: Glantz MH (ed) Climate variability, climate change, and fisheries. Cambridge University Press, Cambridge, pp 213-230

Bemis WE, Kynard B (1997) Sturgeon rivers: an introduction to acipenseriform biogeography and life history. Environ Biol Fishes 48:167-183

Benecke B (1880) Beiträge zur Geschichte der Fischerei in Ost- und Westpreussen. Altpreussisch Monatsschrift 17:300-322

Benecke N (1986) Some remarks on sturgeon fishing in the southern Baltic region in medieval times. In: Brinkhuizen DC, Clason AT (eds) Fish and archaeology. BAR International, Oxford, pp 9-17

Biganti T (1995) La pesca nel lago Trasimeno: sfruttamento et tutela delle risorse ittiche del lago di Perugia (seccoli XIII$\mathrm{XV}$ ). In: Carucci P, Buttazzo M (eds) Gli archivi per la storia dell'alimentazione. Atti del convegno, Potenza-Matera, 5-8 settembre 1988. Ministero per i Beni Culturali e Ambientali, Ufficio Centrale per i Beni Archivistici, Rome, Italy, pp 772799

Boddeke R (1971) Vissen en vissen: ervaringen van een visserijbioloog en sportvisser. Elsevier, Amsterdam, The Netherlands

de Boer DEH (1997) 'Roerend van der visscheryen' Enkele aspecten van de visvangst in Holland en Zeeland tot de Sint Elisabethsvloed van 1421. In: Beenakker JJJM et al. (eds) Holland en het water in de middeleuwen. Strijd tegen het water en beheersing en bruik van het het water. Verloren, Hilversum, pp $115-140$

Bork HR (1988) Bodenerosion und Umwelt. Verlauf, Ursachen und Folgen der mittelalterlichen und neuzeitlichen Bodenerosion, Bodenerosionprozesse, Modelle und Simulationen. Technische Universität, Braunschweig

Bourlet C (1995) L'Approvisionnement de Paris en poisson de mer aux $\mathrm{XIV}^{\mathrm{e}}$ et $\mathrm{XV}^{\mathrm{e}}$ siècles, d'après les sources normatives. FrancoBritish Stud 20:5-22

Brázdil R (2002) Patterns of climate in central Europe since viking times. In: Wefer $\mathrm{G}$ et al (eds) Climate development and history of the North Atlantic Realm. Springer, Berlin Heidelberg New York, pp 355-368

Brázdil R (2003) Historical climatology and its progress after 1990. In: Laszlovszky J, Szabó P (eds) People and nature in historical perspective. Central European University, Department of Medieval Studies and Archaeolingua, Budapest, Hungary, pp 197-228 
Brázdil R, Kotyza O (1995) History of weather and climate in the Czech lands, vol. 1: Period 1000-1500. Geographisches Institut, Eidgenössische Techniche Hochschule Zürich, Zürich, Switzerland

Bresc H (1986) Un monde méditerranéen. Économie et société en Sicilie 1300-1450. Ecole Française, Rome, Italy

Bresc H (1987) La pêche dans l'espace économique normand. In: Musca G (ed) Terra e uomini nel Mezzogiorno normannosvevo. Atti delle settime giornate normanno-sveve, Bari 15-17 ottobre 1985. Centro di studi normanno-svevi Università degli Studi di Bari, Bari, Italy, pp 271-291

Bruijn JR (1996) Dutch fisheries: an historiographical and thematic overview. In: Holm P, Starkey DJ, Thor JT (eds) The north Atlantic fisheries, 1100-1976: National perspectives on a common resource. Fiskerei- og Søfartsmuseets Forlag, Esbjerg, pp $105-120$

Carlson CC (1996) The (in)significance of Atlantic Salmon. Fed Archeol 8(3/4):22-30

Clason AT, Prummel W, Brinkhuizen DC (1979) Vogelen en vissen. Een glimp van de Nederlandse vogel- en viswereld uit het verleden. Westerheem 28:9-22

Clavel B (2001) L'Animal dans l'alimentation médiévale et moderne en France du nord (XIIe - XVIIe siècles). Revue Archéologique de Picardie, No. Spécial 19. CRAVO, n.p.

van Dam PJEM (1998) Vissen in veenmeren. De sluisvisserij op aal tussen Haarlem en Amsterdam en de ecologische transformatie in Rijnland 1440-1530. Historische Vereniging Holland Uitgevereij Verloren, Hilversum

Dunin-Wạsowicz T (1990) Natural environment and human settlement over the central European lowland in the thirteenth Century. In: Brimblecombe P, Pfister C (eds) The silent countdown. Essays in European Environmental History. Springer, Berlin Heidelberg New York, pp 92-105

Enghoff IB (1999) Fishing in the Baltic region from the fifth century B.C. to the sixth century A.D.: evidence from fish bones. Archaeofauna 8:41-85

Enghoff IB (2000) Fishing in the southern North Sea region from the first to the sixteenth century A.D.: evidence from fish bones. Archaeofauna 9:59-132

Filuk J (1968) Biologiczno-rybacka charakterystyka ichtiofauny zalewu wiślanego na tle badań paleoichtiologicznych,historycznych i wspólczesnych. Pomorania Antiqua 2:119175

Gemmill E, Mayhew N (1995) Changing values in Scotland: a study of prices, money, and weights and measures. Cambridge University Press, Cambridge, UK

Glantz MH (1992) Climate variability, climate change, and fisheries. Cambridge University Press, Cambridge, UK

Glaser R (2001) Klimageschichte Mitteleuropas. 1000 Jahre Wetter, Klima, Katastrophen. Wissenschaftliche Buchgesellschaft, Darmstadt, Germany

Grove J (1996) The century time-scale. In: Driver TS, Chapman GP (eds) Time-scales and environmental change. Routledge, New York,USA, pp 39-87

Grove AT, Rackham O (2001) The nature of Mediterranean Europe: an ecological history. Yale University Press, New Haven, USA

Halard X (1983) La pêche du saumon en Normandie du XIe au XVe siècle. J Medieval Hist 9:173-178

Hocquet J-C (1987) Les pêcheries médiévales. In: Mollat M (ed) Histoire des pêches maritimes en France. Privat, Toulouse, France, pp 36-129

Hodgson WC (1957) The herring and its fishery. Routledge, London, UK

Hoffmann RC (1994) Remains and verbal evidence of carp (Cyprinus carpio) in medieval Europe. In: Van Neer W (ed) Fish exploitation in the past. Proceedings of the 7th meeting of the I.C.A.Z. Fish Remains Working Group. Musée Royal de l'Afrique Central, Tervuren, Belgium, pp 139-150

Hoffmann RC (1996) Economic development and aquatic ecosystems in medieval Europe. Am Historical Rev 101:631669
Hoffmann RC (2000) Medieval fishing. In: Squatriti P (ed) Working with water in medieval Europe: technology and resource use. Brill, Leiden, The Netherlands, pp 331-393

Hoffmann RC (2001) Frontier foods for late medieval consumers: culture, economy, ecology. Environ Hist 7:131-167

Hoffmann RC (2002) Carp, cods, connections: new fisheries in the medieval European economy and environment. In: HenningerVoss MJ (ed) Animals in human histories: the mirror of nature and culture. University of Rochester Press, Rochester, NY, pp $3-55$

Jahnke C (2000) Das Silber des Meeres. Fang und Vertrieb von Ostseehering zwischen Norwegen und Italien (12.-16. Jahrhundert). Böhlau, Köln, Germany

Krovnin AS, Rodionov SN (1992) Atlanto-Scandian herring: a case study. In: Glantz MH (ed) Climate variability, climate change, and fisheries. Cambridge University Press, Cambridge, UK, pp 231-260

Lanconelli A (1985) Gli Statuta pescivendulorum urbis (1405). Note sul commercio di pesce a Roma tra XIV e XV secole. Archivio della Societa romana di storia patria 108:83-131

Leciejewicz L (1985) Z denara otrzymasz wóz świeżych śledzi. In: Kuczyński SK et al. (eds) Nummus et historia. Pieniadz Europy średniowiecznej. PAN, Warsaw, Poland, pp 103-109

Leciejewicz L (1991) Zum frühmittelalterlichen Heringshandel im südlichen Ostseegebiet. Z Archäol 25:209-214

Ludwig A, Debus L, Lieckfeldt D, Wirgin I, Benecke N, Jenneckens I, Williot P, Waldman JR, Pitra C (2002) When the American sea sturgeon swam east. Nature 419:447-448

Martens J (1997) Die mittelalterlichen Gartensiedlungen in Preussen. Institut Nordostdeutsches Kulturwerk, Lüneburg, Germany

Materné J (1988) Beroeps- en vrijetijdsvisserij op de Vlaamse binnenwateren tussen Antwerpen en Gent vóór de industriële revolutie. Bijdr Geschied 71:141-172

Munro JH (1994) Patterns of trade, money, and credit. In: Brady TA, Oberman HA, Tracy JD (eds) Handbook of European history 1400-1600. Late Middle Ages, Renaissance and Reformation, vol. I: Structures and assertions. Brill, Leiden, The Netherlands, pp 147-195

Pfister C, Schwarz-Zanetti G, Wegmann M (1996) Winter severity in Europe: the fourteenth century. Clim Change 34:91-108

Plouchard P (1997) La Scarpe et les gens der rivière. In: Racine R (ed) Fleuves, rivières et canaux dans l'Europe occidentale et médiane. CRDP Lorraine, Nancy, France

Scully T (1995) The art of cookery in the Middle Ages. Boydell, Woodbridge, UK

Stolz O (1936) Geschichtskunde der Gewässer Tirols. SchlernSchriften, Innsbruck, Austria

Trexler R (1974) Measures against water pollution in fifteenth century Florence. Viator 5:455-467

Unger RW (1978) The Netherlands herring fishery in the late Middle Ages: the false legend of William Beukels of Biervliet. Viator 9:335-356

Unger RW (1980) Dutch herring, technology, and international trade in the seventeenth century. J Econ Hist 40:253-280

Van Neer W, Ervynck A (1993) Archeologie en Vis. Herlevend Verleden, 1. Instituut voor het Archeologisch Patrimonium, Zellik, Belgium

Vendittelli M (1990) La pesca nelle acque interne del territorio ninfesino. Tecniche di sfruttamento ed interessi di gestione. In: Fiorani L (ed) Ninfa, una città, un giardino. Atti del Colloquio della Fondazione Camillo Caetani, Roma, Sermoneta, Ninfa, 7-9 ottobre 1988. L'Erma di Bretschneider, Rome, Italy, pp 113-137

Vendittelli M (1992) Diritti ed impianti di pesca degli enti ecclesiastici Romani tra X e XIII secolo, Melanges de l'ecole francaise de Rome. Moyen Age 104:387-430

Vincenti V (2002) La tutela ambientale del Lago Trasimeno in eta medioevale. Environmental protection of lake Trasimene in the Middle Ages. In: Robinson TM, Westra L (eds) Thinking about the environment: our debt to the classical and medieval past. Lexington Books, Lanham, MD, pp 130-140 
Wiessner E (ed) (1931) Heinrich Wittenwilers Ring. Reclam, Leipzig , Germany

Wiessner E (1936) Kommentar zu Heinrich Wittenwilers Ring. Reclam, Leipzig, Germany

Willam HA (1961) Die Fischerei des Deutschen Ordens in Preussen bis zu Dietrich von Altenburg. Jahrbuch der Albertus-Universität zu Königsberg/Pr 11:64-152
Zimmermann G (1973) Ordensleben und Lebensstandard. Die Cura Corporis in den Ordensvorschriften des abendländischen Hochmittelalters. Aschendorff, Münster, Germany 